\title{
Hepatitis B antigen and antibody in a male homosexual population
}

\author{
J. C. COLEMAN, M. WAUGH,* AND R. DAYTON \\ From the Departments of Microbiology and Venereology, \\ Charing Cross Hospital (Fulham), London
}

SUMMARY Sera from 600 male homosexual patients were tested for hepatitis B antigen (HBs Ag) and its antibody (HBs Ab). Thirty-one men (5.2\%) were positive for HBs Ag. Testing for $\mathrm{HBs} \mathrm{Ab}$ by immuno-osmoelectrophoresis 33 men $(5 \cdot 5 \%)$ were positive. However, sera of 85 patients negative for $\mathrm{HBs} \mathrm{Ab}$ by routine methods were examined for $\mathrm{HBs} \mathrm{Ab}$ by radioimmune assay. Thirty $(35 \%)$ sera were found to be positive. No absolute correlation between the detection of HBs Ag, or previous history of hepatitis, jaundice, or current hepatitis was found. Similarly there was little correlation between presence of $\mathrm{HBs} \mathrm{Ab}$ and this history. These observations suggest that the male homosexual population represents a pool of individuals within which the hepatitis B virus is readily transmitted, mainly as a subclinical infection although clinical hepatitis does occur in some patients. It is suggested that further work is necessary to determine whether the high antibody rate in male homosexuals is related more to sexual practice than to promiscuity.

\section{Introduction}

An association between the incidence of hepatitis B antigen, its antibody, and sexual activity has been described by several authors (Vahrman, 1970, 1973; Heathcote and Sherlock, 1973; King, 1974). A significantly higher incidence of hepatitis B antigen ( $\mathrm{HBs} \mathrm{Ag}$ ) was found among patients attending clinics for sexually transmitted diseases than in a new blood donor population (Fulford et al., 1973). Within this population the male homosexual patients are most frequently positive for $\mathrm{HBs} \mathbf{A g}$ (Jeffries et al., 1973).

At the West London Hospital some 27 to $31 \%$ of the male patients who attend the Department of Genito-Urinary Medicine admit to homosexual practices (Fluker, 1974).

The survey was performed to investigate the incidence of $\mathrm{HBs} \mathrm{Ag}$ and its antibody (HBs $\mathrm{Ab}$ ) in a large homosexual population.

Address for reprints: Dr J. C. Coleman, Department of Microbiology, Charing Cross Medical School, Fulham Palace Road, London W6 8RF

*Present address: Department of Sexually Transmitted Diseases, The General Infirmary, Leeds

Received for publication 5 July 1976

\section{Patients and methods}

Between 11 February 1974 and 24 January 1975, 600 male homosexual patients were admitted to the survey. At the time of consultation each patient was asked if he had a previous history of jaundice, hepatitis, or other liver disease. The replies to these questions were recorded. Because there is a marked geographical variation in the incidence of $\mathrm{HBs} \mathrm{Ag}$ carriage and $\mathrm{HBs} \mathrm{Ab}$ detection the country of origin of each patient was noted. In addition to investigation of the presenting venereological symptoms, blood was taken and sent to the virology laboratory.

$\mathrm{HBs} \mathrm{Ag}$ was detected by immuno-osmoelectrophoresis (IOEP) and by reverse passive haemagglutination of antibody-coated sheep cells (Hepanosticon, Organon Technika). For most of the survey HBs Ab was detected by IOEP. Ninety HBs Ag negative sera were tested for $\mathrm{HBs} A b$ by radioimmune assay (RIA). Of these sera, five had been found positive for HBs $A b$ by IOEP and were included as internal standards, the remaining 85 had been reported as HBs Ab negative by IOEP.

\section{Results}

The mean age of these 600 men was $29 \cdot 3$ years, ranging from 16 to 64 years. 
Thirty-one men $(5 \cdot 2 \%)$ were positive for $\mathrm{HBs} \mathrm{Ag}$. Twenty-eight $(4.7 \%)$ gave a history of jaundice, hepatitis, or liver disease of whom only five $(0.8 \%)$ were found to have $\mathrm{HBs} \mathrm{Ag}$. Only one patient was clinically jaundiced at the time of examination. The association of patient age with a positive $\mathrm{HBs} \mathrm{Ag}$ test is shown in Table 1 . The country of origin of the patients was: British Isles 22; USA 4; Australia 2; South Africa 1; Spain 1; China 1. With the exception of the Chinese patient, all were Caucasian.

In the first series of the tests for HBs Ab by IOEP the following results were obtained. Thirty-three men $(5.5 \%)$ were found to be positive. Only five patients with $\mathrm{HBs} \mathrm{Ab}$ gave a history of hepatitis, jaundice, or liver disease.

Table 1 Age distribution of $\mathrm{HBs}$ Ag patients

\begin{tabular}{lrc}
$\begin{array}{l}\text { Age group } \\
\text { (years) }\end{array}$ & No. & $\begin{array}{l}\text { No. } \\
\text { positive }\end{array}$ \\
\hline $16-20$ & 36 & 3 \\
$21-25$ & 146 & 6 \\
$26-30$ & 211 & 10 \\
$31-35$ & 102 & 7 \\
$36-40$ & 48 & 3 \\
$41-45$ & 35 & 2 \\
$46-50$ & 12 & - \\
$51-55$ & 7 & - \\
$56-60$ & 1 & - \\
$61-65$ & 2 & - \\
\hline
\end{tabular}

Of the sera of 85 patients negative for $\mathrm{HBs} A b$ by routine methods and examined for $\mathrm{HBs} \mathrm{Ab}$ by RIA, $30(35 \%)$ were found to be positive. Only three patients shown to have antibody by RIA gave a history of jaundice or hepatitis. One other patient had attended his general practitioner who had made a clinical diagnosis of glandular fever. Two patients who lived together had both had hepatitis, one in December 1974 and the other in January 1975. Only one patient with $\mathrm{HBs} \mathrm{Ab}$ was known to be a contact of a patient with HBs Ag. An association of patient age with a positive $\mathrm{HBs} \mathrm{Ab}$ result, by either method, is shown in Table 2. The country of origin of the patients was: British Isles 58; Canada 1; Australia 1; South Africa 2; Spain 1. All were Caucasian.

\section{Discussion}

The incidence of $\mathrm{HBs} \mathrm{Ag}$ in volunteer blood donors in the United Kingdom varies from about 1:500 to $1: 1000$ (Zuckerman, 1975). The detection of HBs Ag in $5.2 \%(31 / 600)$ of the male homosexual patients attending the Department of Genito-Urinary Medicine confirms the finding by Jeffries et al. (1973) of a relatively high incidence of $\mathrm{HBs} \mathrm{Ag}$ in male
Table 2 Age distribution of $H B s$ Ab patients

\begin{tabular}{ll}
\hline $\begin{array}{l}\text { Age group } \\
\text { (years) }\end{array}$ & $\begin{array}{l}\text { No. with } \\
\text { antibody }\end{array}$ \\
\hline $16-20$ & - \\
$21-25$ & 9 \\
$26-30$ & 27 \\
$31-35$ & 12 \\
$36-40$ & 7 \\
$41-45$ & 4 \\
$46-50$ & 2 \\
$51-55$ & 2 \\
$56-60$ & - \\
$61-65$ & - \\
\hline
\end{tabular}

homosexuals in London. Similarly Vahrman (1973) showed that the correlation between homosexuality and clinical viral hepatitis was highly significant. In his series of 32 men with $\mathrm{HBs} \mathrm{Ag}$ positive hepatitis no fewer than 20 were homosexual.

Although 31 of 600 men gave a positive test for $\mathrm{HBs} \mathrm{Ag}$ only one patient was suffering from hepatitis at the time of detection. The remaining 30 patients were seen sporadically during the survey. None complained of any symptoms of liver disease at any time. Only two patients remained positive for $\mathrm{HBs} \mathrm{Ag}$ at the end of the survey, the remainder having become negative.

With the advent of a highly sensitive radioimmune assay for $\mathrm{HBs} \mathrm{Ab}$, the detection of antibody greatly improved. Whereas 33 men were found positive by IOEP in 600 men, $35 \%$ of 85 sera tested by RIA were positive for $\mathrm{HBs} \mathrm{Ab}$. $\mathrm{HBs} \mathrm{Ab}$ was detected in only four of $276(1.45 \%)$ of blood donor sera tested by RIA at this hospital. As in the case of HBs Ag there was remarkably little correlation between the presence of $\mathrm{HBs} A \mathrm{~b}$ and a history of jaundice, hepatitis, or contact with hepatitis.

These observations suggest that the male homosexual population represents a pool of individuals within which the hepatitis B virus is readily transmitted, particularly subclinical infection. Clinical hepatitis does occur in some patients. The patients with clinically inapparent infection represent a potential hazard to the staff of venereal disease clinics. The risk is offset to some extent because information concerning the sexual habits of the patient is sought during interview, and the appropriate precautions regarding the handling of his blood specimens may be adopted. However this information is not usually sought during general medical or dental examination and the symptomless positive homosexual patient may present a greater risk to medical and dental staff in other areas of medical practice. Reinicke et al. (1972) have suggested that those who are persistently HBs Ag positive with evidence of liver dysfunction are more infectious than those with normal liver function. 
Biochemical tests of liver function should be performed on those patients found to be carrying HBs Ag.

Vahrman $(1970,1973)$ claimed that hepatitis B might be sexually transmitted. Further evidence for this view was produced by Hersh et al. (1971), Heathcote and Sherlock (1973), and Fulford et al. (1973). The results of this study confirm these observations. As an indicator of past cumulative experience of $\mathrm{HBs} \mathrm{Ag}$ a sensitive technique - that is, radioimmune assay-for the detection of $\mathrm{HBs} A b$ is probably of more value than detection of the HBs Ag carrier rate. Papaevangelou et al. (1974) studied hepatitis $B$ antigen and antibody rates in prostitutes. They suggested that the increased incidence of $\mathrm{HBs} \mathrm{Ab}$ in older prostitutes was, in part, associated with the duration of prostitution. It is possible that the increased incidence of antibody with age is the result of intermittent exposure to small doses of antigen by a non-parenteral route. Further work is necessary to determine whether the high antibody rate in male homosexuals is related more to sexual practice than to promiscuity. In this context it is of interest that $25(80.7 \%)$ of the 31 patients with HBs Ag had a sexually transmitted infection at the time that the antigen was detected.
Only five (16.1\%) of the patients with HBs Ag gave no previous history of sexually transmitted infection.

\section{References}

Fluker, J. L. (1974). Gonorrhoea. Update, 8, 789-800.

Fulford, K. W. M., Dane, D. S., Catterall, R. D., Woof, R., and Denning, J. V. (1973). Australia antigen and antibody among patients attending a clinic for sexually transmitted diseases. Lancet, $1,1470-1473$.

Heathcote, J., and Sherlock, S. (1973). Spread of acute type-B hepatitis in London. Lancet, 1, 1468-1470.

Hersh, T., Melnick, J. L., Goyal, R. K., and Hollinger, F. B. (1971). Nonparenteral transmission of viral hepatitis type-B (Australia antigen-associated serum hepatitis). New England Journal of Medicine, 285, 1363-1364.

Jeffries, D. G., James, W. H., Jefferiss, F. J. G., Macleod, K. G., and Willcox, R. R. (1973). Australia (hepatitis-associated) antigen in patients attending a venereal disease clinic. British Medical Journal, 2, 455-446.

King, A. J. (1974). Understanding Homosexuality. Its Biological and Psychological Bases, p. 199. Edited by J. A. Loraine. Medical and Technical Publishing: Lancaster.

Papaevangelou, G., Hoofnagle, J., and Kremastinou, J. (1974). Transplacental transmission of hepatitis-B virus by symptom-free chronic carrier mothers. Lancet, 2, 746-748.

Reinicke, V., Dybkjaer, E., Poulsen, H., Banke, O., Lylloff, K., and Nordenfelt, E. (1972). A study of Australia antigen-positive blood donors and their recipients, with special reference to liver histology. New England Journal of Medicine, 286, 867-870.

Vahrman, J. (1970). Transmission of hepatitis. Lancet, 2, 774.

Vahrman, J. (1973). Spread of acute type-B hepatitis in London. Lancet, 2, 157.

Zuckerman, A. J. (1975). Human Viral Hepatitis, p.54. North-Holland: Amsterdam and Oxford. 